\title{
Didacticism and Philosophical Tenets in Ọbasa's Poetry
}

\author{
Arinpe Adejumo \\ Department of Linguistics and African Languages \\ University of Ibadan \\ Nigeria \\ agadejunmi@yahoo.com
}

\begin{abstract}
Projection and promotion of Yoruba cultural ideology and philosophy are motifs in D.A. Obasa's poetry. As an ingenious poet, Obasa adroitly blends the tropes of didacticism and philosophical tenets in his poetry. Existing works on his poetry have explored the thematic preoccupations of his poems, as well as their forms and stylistic features. However, little attention has been paid to the correlation between didacticism and philosophy in his poetry. This essay, therefore, identifies the basic tenets of philosophy in the form of ethical, metaphysical, and epistemological aspects of Yoruba philosophy in Obasa'a poetry with a view to establishing the way Yoruba philosophy is used to teach morals in the poems. Obasa's philosophical inclination is anchored on Yoruba philosophy. Some of the philosophical tenets identified are ethical issues, like obedience, truth, hospitality and being respectful. Virtues are extolled, while vices, like jealousy, pride, disobedience and deceit are condemned. The metaphysical beliefs of the Yoruba in death, destiny, and life after death, as well as the belief in the Supreme Being (Olodumare) are also discussed. The epistemological values of Yoruba communal system and ìwà, and omọlúàbi concept are also entrenched in Obasa's poetry. It is also revealed that satirical elements, especially humor are used to project Yoruba philosophical belief in order to imbue the reader with moral rectitude. There is a close link between Obasa's poetry and the Yoruba sociocultural milieu. The essence of didacticism and philosophical tenet in his poems is to advance the social development of the Yoruba society and the larger Nigerian society.
\end{abstract}




\section{Introduction}

The works of Obasá, a veteran Yorùbá poet, have been the focus of literary critics. Notable among the critics are Olambitan $(1974,1975)$, Ogunsina (1991), and Akinyemi (1987; 1991; 2017). All the three scholars have examined the issues of form, style, and themes in Obasa's poetry. It has been established that Obasa aims at a systematic collection of Yoruba traditional sayings in order to bring to the fore Yoruba beliefs and thoughts for preservation and documentation (Akinyemi 2017). Citing Babalola and Gerard (1971), Akinyemi (2017) emphasizes the fact that through Obasa's poems the interrelationship between the traditional beliefs and writing in the modern era has been established. Olabimtan (1975) avers that “Obasá's greatness consists in his ability to assemble traditional sayings...which embody the traditional wisdom of Yoruba society" (1032). Many of the Yoruba traditional sayings which Obasa assembled in his poems are products of the Yoruba philosophy, hence, Obasa sub-titled his poetry collection "Yorùbá Philosophy." According to Akinyemi (2017), Obasá aims at popularizing Yoruba cultural values. He argues that:

Obasá deserves credit for popularizing a vision of poetry that assigns it definite social value, especially in its utility in instructing, correcting and influencing conduct. This implies that Obasá is placed on an elevated moral platform that enables him to use his poetry to inform, correct and educate his readers. This is exemplified by unique didactic precepts from Yoruba oral literature inscribed in many Obasá's composition ... (9-10)

The above position corroborates Olatunji's (1982) claims that entertainment and didacticism are central to poetry in Obasá's era. Specifically, he states that "didacticism syndrome" started with poetry of Șówandé (Șóbọ Aróbíodu), Obasá, Ajísafẹ and Odúnjọ (24). The didacticism syndrome, according to Olatunji, could be traced to missionary education, which aimed at moralizing. Trends in the Yoruba creative writings at inception affirm the above opinion, hence, earlier Yoruba writers pre-occupied their works with didactic elements.

It could be deduced from the above position that both Yoruba traditional sayings assembled by Obasá and his own original creation, which formed his poetry, are composed for didacticism. Using an eclectic approach combining philosophical and sociological insights, this paper, therefore, examines the philosophical tenets in Obasá's poems. It discusses the didactic import of Ọbasá's philosophical disposition with a view to determine the correlation 
between poetry and philosophy as well as the correlation between the identified philosophical tenets and didactic elements projected in the poems.

\section{Obasa: A Philosopher-poet}

The moral question as it affects social, political and human development, is the focus of poems (Olabimtan 1988). Even in the traditional Yoruba setting, the desire to have good governance, peace, harmony, and sustainable development are the focal points on which the traditional poems are composed and performed (Adeleke, 2007; Adejumo, 2008; 2017). Yoruba philosophical thoughts and beliefs are the pivot on which these traditional poems rest. Obasa poems are rich in Yoruba worldview. Aspects of global philosophy are also projected in his poems. The three aspects discussed here are metaphysics, ethics and epistemology. However, aspect of ethics and moral values are preponderant in his poems.

\section{Philosophical Issues in Ọbasá's Poetry}

Metaphysics, a branch of philosophy that addresses the issue of being and existence as well as reality of things, is projected in Obasa's poems. Some of the metaphysical concepts identified are the Yorùbá belief in the Supreme Being (Olodumare) destiny (àyànmọ́/àkúnlẹyàn), death (ikú) and life after death (àșèyinwáyé). In four of his poems, "Oore," "Ifẹ Ėtè," "Ộọ ẹ̣hìn," and "Ėrè-Ișẹ," the nature and attributes of Olodumare are revealed. The Supreme Being is revealed as the giver of life and the one who sees everything and who will reward human deeds here on earth:

\section{Excerpt I}

Ọlọrun nii sèsan

Igbá tá a bá $n$ wín kà

Òun làáfi sán ọkà.

Olọ́run Oba kòkòyí bèèrè

Òun lolórí Elééésú

Òun lọba Elẹsan (Ọbasá1927: 8).

God is the rewarder

The measure that we used to measure (for others)

It is the same that will be used to measure back to us

God, the unquestionable King

Is the master thrift collector

$\mathrm{He}$ is the Avenger 
The above belief is further emphasised in "Erè Isẹ":

Excerpt II

Olọ́run láilái ní i ti i pé

Kí o tó mú ni

Olọ́rún tìwòyí kò pé

Esin ní ń gùn gbèjà

Eni tá ò lè mú

Olọrun là á fií fún!

Ká fijà Folọ́run jà

Ká fọwọ lẹrán. (Ọbasá1934:16).

The God of olden days

Takes time before he avenges

The God of nowadays is quick in action

He avenges in a lightning speed

Somebody who is more powerful than one

Should be handed over to God

Hand over your battle to God

And stand aloof.

The attributes of God as King in Excerpts I \& II, are in line with the Yoruba worldview on the supremacy of the institution of obaship. Oba, the Yoruba king, is a powerful and respected leader. He is referred to as kábíyèsí- ká-bi-1́ò-sí. (No-one-can-question-his-acts-and-doings). In the Yoruba belief, handing over one's life challeges to Olodumare will yield a more profitable result than finding human solutions to the challenges. The philosophical question that may come to mind now is: Why is it more dangerous for a villain to be handed to God? One, God is the Supreme Creator; he created all humans; he knows their weaknesses and strengths; and it is his life that humans are using to breathe. He knows best to punish an offender and the degree of punishment to be awarded to the offender. Nobody can query him. If a victim decides to avenge himself it may even get him/her in trouble. In order not to get oneself in trouble while avenging for oneself, it is better to allow God's judgment to prevail. The didactic import of God's existence and his Supremacy in the affairs of man is depicted in the last portion of Excerpt II: Ká fijà fọ́lọrun jà, ká fọwo ẹ ẹ́rán because He (Olodumare) will avenge man of his enemies more than what man could do. The above position is in tandem with Olajide's (2012) view of Olodumare: 
The existence of God (Olódùmare or Àjàlọrun) as he is usually called ) is taken for granted as given. He is conceived of as the giver of life, the sustainer of the universe and the ultimate source of which man and all other things must return... God is conceived of as the greater and source of being. He therefore made man (37).

God as the source of being is also paramount in the poetry of Obasa. In "İkà-Èké" he highlights how God created all things and with his omniscient attributes he decided to measure the extent of innate ability, resistance, power, and physiology he gave to all his creation.

Excerpt III

Olọ́run kò dá kainkanyin

Kó ní ńlá bí esin

Àtapa ní i bá ta ni

Àtapa ní i bá tànìyàn!...

Adiẹ i bá lộkọ́

İbá fàkitàn șe nǹkan!...

İmàdò i bá ṣe bí ẹlẹdẹ

A bà'lú jẹ,

Erú ì bá jọba Ènia ì bá ti kuù kan ṣoṣo! (Ọbasa 1927:9).

God did not create the ant

To be as big as the horse

It would have kicked and trample one to death

It would have kicked and trampled human beings to death!

Had it been that the hen has a hoe

It would have dealt brutally with the dunghill

Had it been that wild boar is like the pig

The city would have been destroyed

If a slave is enthroned as a king

He would have ruined the city!

The above excerpt, clearly reveals that God, with his supreme power, has set order in the world. Through his omniscient power, he knows the frailty of his beings and he has carefully set a control in order to set a social order that will promote peace and tranquility. For instance, as small as the ant is, its venom is painful. One would now begin to imagine if the ant had been bigger than the way it is, it would have been dangerous and harmful. Also, the tiny feet given to the hen is used to scavenge the dunghill, while the wild boar deals with the mud much more than the pig. In essence, the control of power and 
power relation is in the hand of the invisible and Supreme God who created all humans. The didactic import of this is that whoever is bequeathed with a measure of power should use it right. In concluding the poem Obasá says:

Excerpt IV

İkà kò jẹ paramọlẹ ó dàgbà

A níkà nínú b’ì baakà!

A-ta-kóró wonú àdó

omo rèn noó

Aya rẹ ńkọ??

Àgbà tó gbièbú ikà

Lórí ọmọ rẹ ní yío hùlé...

Eni tín șe rere

Kó múra sí rere íṣe;

Eni tí ń sikà

Kó máa șeèkà ǹsó;

Atoore, àtìikà

ọłkan kì í gbé! (Obasa 1927: 12).

Evil did not allow viper (night-adder) to grow

The man that is callous as the Mule

I am- armed with metaphysical power!

Are your children also armed?

Is your wife armed?

An elderly person that plants wickedness

His children shall harvest evil

If you are virtuous

Continue to be virtuous

If you are wicked

Continue in wickedness

Both virtues and vices

Shall be rewarded!

Another existence of being is also deduced from Excerpt IV above. Human beings are created by Olodumare, but humans also have a part to play in making sure that they exist for long. Hence, the issue of marriage. In the Yoruba worldview, anyone who does not have children is regarded as a failure in life. Hence, one of the things the Yoruba desire from Ờúnmilà, the witness of every human destiny, is children. Olatunji (1984:118) aptly captures the above view, he asserts that "Desire for children appears to be the most recurrent in ẹsẹ Ifá, for the Yorùbá consider childlessness a misfortune, and children 
are regarded as a major part of a man's greatness and success" (118). Obasá's poem corroborates the above view when he says for human to exist he/she has to have his/her own children:

\section{Excerpt V}

Omọ dáyá rẹ lójú

Bí a bá lọ s'ájò

Bía kò síninú ilé

Omo ẹni á wo'lé de ni ...

Bẹ́kọ bá kù kán

Omo ẹni un la á fún un jẹ!

Abiamọ kì í kú, Ẹhìn nií fi ít’òpó! (Ọbasá 1934:18).

The mother trusts her child

If one goes on a journey

If one is not around at home

It is the child that takes care of one's home

If the pap-ball remains

It is given to one's child

A mother never dies

She only goes on transition.

Three philosophical thoughts will be discussed from Excerpts IV and V. One is the importance attached to procreation and bearing of children among the Yoruba. To the Yoruba, anybody that has a child is believed to exist forever; hence the prayer ò ò níí kú láéláé; (you shall never die). A person is believed to be in existence for life, if he or she has children that live after him/ her; hence the saying abiamọ ki i kú (A mother never dies) in Excerpt V.

Excerpt IV shows that it will be disastrous that after all the desire to have children in order to prolong one's existence in life, what one now bequeaths to one's child is curse and evil, because àgbà tó gbin èèbu ikà, orí ọmọ rẹ ni yóo hù lé (an elderly that planted evil, his children shall harvest wickedness). If this is the case, the essence of existence of such a person is already jeopardised. The didactic significance of this excerpt is that for human to really exist, they must conform to what is acceptable as "good" always.

The second is the fact that man is on earth to assist God in re-creation of man through procreation. However, as man's creation and re-creation continue, death is imminent. Here, àjò (journey), within the context of the poem can mean physical travelling or eternal travelling because, as God is the giver of life, he is also the "ultimate source to which man and all other things must return." If man now lives with this consciousness, it is pertinent to conform 
to what is regarded as good always and train one's children in a way that they will keep one's existence for life. This is encapsulated in the poem "Àkẹjù and Òmùgọ":

\section{Excerpt VI \\ Gọngọsú Èdidàré \\ Eni tó bímọ ti kò gbọn \\ Iná jó o tàbí ko jó o? \\ A ni "ọmọ rẹ kò gbọn" \\ O ni kí sa ma kú" \\ Kini ni hà á p’ọmo \\ Bí kò șagọ \\ Orí ńfọmọ kò lè wí \\ Inú ń run ọmọ kò lè so \\ À ní Níbo ni ń dùn ọ? \\ Omọ ń sunkún sá...}

Gbàwo lọmọ ò ní kú? (Ọbasá 1934: 19).

A fool of Edidare

Whoever bore an unwise child

Is he doomed or not?

We say your child is unwise

You responded that he should not die

What kills a child like lack of wisdom

A child is suffering of headache

He could not express himself

He is suffering of stomach ache he kept mute

We enquired from him of the actual place he is suffering pain

He keeps on weeping

Will the child not die?

The following excerpt is an emphasis of the essence of wisdom and child's proper upbringing.

\section{Excerpt VII}

Bomọ ẹni kò bá gbọn

A ki i í ẹlo rán an nisé

Baba ni bí e ti ń lọ yiú,

Bí e bá disú tán

Kí ẹ tan ná ran'ba oko 
Omùgọ a fifún rin

Omo disu tán l'óko

O tanná ran'ba dandan

Nwọn ni Ha ha ha!

Èmi ló șè yìr?

O ní Bàbá on ló ní

B’on bá diṣu tán

K'on tan'ná ran abà oko!

Ǹ jẹ bọmọ ẹni kò bá gbọ́n

A ki í ran a nísẹ lệlọ-ǹ-lọ! (Ọbasá 1934: 20).

If a child is unwise

Do not speak irony to him when sending him on errand.

Father said 'As you are going'

After tying the yams

Make sure you set the barn on fire

A fool that walks with his intestine

He tied the yams

And set the barn on fire

And after a great pandemonium

The question was asked 'why did you set the barn on fire?"

He responded "it was father's instruction that

I should set the barn on fire after tying the yam".

If your child is not wise

Don't speak to him ironically!

From excerpt VII above, the vivid illustration of the behavior of a foolish child is to emphasis the essence of training a child properly, in order to affirm the Yoruba philosophy of real existence. The action of the unwise child in the excerpt above could lead to both material and spiritual death and this may end one's existence physically and eternally. The peak of the didacticism in the excerpt is the last line. It could be averred that different strokes should be for different people. Parents should nurture their children in wisdom. They should take cognizance of the level of knowledge and experiences of their children.

The third philosophical issue revealed in Excerpt $\mathrm{V}$ is the issue of death. This is further exemplified in his poem titled "Ikú."

Excerpt VIII

Aiye lajò, Ờrun nilé

Bí a bá kú láíyé 
A ó ò rộrun re simi

Àsikò la ò mọ

Omọé a máa kú

Àgbà a rìnrìn a sọnù

Kò sẹni tíkú kò lè kàn (Ọbasá 1934: 22).

The world is a journey, heaven is our home

If we die on earth

We shall go and rest in heaven

It's just that nobody knows the time of his/her death

Young children die

Adults also die

Death is inescapable

The above excerpt aptly explains the Yoruba existential belief in death as an inevitable end of man, as all humans will return to Olodumare the giver of life. It is also revealed that death is not limited to the elderly, anybody can die at any time. The question of dying at a younger age or at old age, is also answered in the same poem, as seen below:

Excerpt IX

Sákùnlè yàn òun làdáyé rí

İgbèyin ayé kò lu mọ (Ọbasá 1934: 22).

That which is chosen kneeling down

Is what one is seeing on earth

Nobody knows the end of the world.

The above excerpt is in line with the Yoruba belief in destiny. According to Abimbola (1975) and Olatunji (1984), and other African Philosophers, like Olajide (2012) and Bamikole (2016), man's success, failure, expoilt on earth and death have been predestined by the person's ori (the inner-being). Orí is a detailed blueprint of one's earthly life till death. If a person chose a good head (inner-being) from Àjàlá Alámọ (Abimbola 1975) while coming to earth, such a person will do well on earth. But if a person chose a bad inner-being such a person will not prosper on earth. This explains why somebody can die young and another person can die at old age; it is what they chose while kneeling to receive their destiny before birth. This metaphysical doctrine of determinism is also portrayed in Obasa's poem titled "Ẹwà":

\section{Excerpts X}


İwà lẹwà

Morí lọ

Má mẹwà lo

Òòjọ́ lẹwà á bọ

Orí ní i bá ni gbélé ọkọ. (Ọbasá 1945: 24).

Character is beauty

Go with your inner being

Do not go with your beauty

Beauty will return the same day

While your inner being will

Ever remain with one in one's matrimonial home

Within the framework of Yoruba philosophy as portrayed in Ifa literary corpus, it is only one's orí (the inner being) that can accompany one on one's farthest journey in life and will never forsake one. This is as portrayed in Odù Ògúndá Méjì:

Ờrúnmilà ló dọdẹdẹ nì bẹrẹ

Ifá, mo ní 'Ta ló tó Alásàán bá rokun?

Orínkan

Lótó Alásàán bá ròkun

Bí mo bá lówó lọwọ

Orí ní ń ó rò fún

Orí i mi iwo ni

Bí mo bá bímọ láyé

Orí ni ń ó rò fún

Orí i mi iwo ni

Ire gbogbo ń mo bá ní láyé

Oríi mi iwo ni (Abimbola 1983: 92).

Orùnmilà said that on entering a room

One stoops down at the doorway

Ifa, the question is ' who among the

gods can accompany his devotee

On a distant journey over the seas

Without turning back?

It is Ori alone

Who can accompany his devotee

To any place without turning back

If I have money 
It is my Ori I will praise

My Ori, it is you

If I have children on earth

It is my Ori to whom I will

Give the praise

My Ori, it is you

All good things I have on earth

It is Ori I will praise

My Ori, it is you. (Abimbola's translation)

According to Yoruba belief and as portrayed in Excerpts IX and X above, ori is unalterable and irrevocable. However, some scholars hold contrary opinion, arguing that one's destiny may be altered. As noted by Idowu (1962) and Makinde (1983) there are different ways in which one's destiny may be altered. These are highlighted in Olajide (2012) as follows:

(a) Appealing to Orunmila the arch-divinity can change one's destiny from bad to good.

(b) Ọmọ ará-ayé, the children of the world, known as earthly re-creation can change one's destiny from good to bad.

(c) One's own unpleasant character (attitude) like pride, laziness, impatience, inordinate ambition can change one's destiny from good to bad.

(d) Becoming a devotee of Ộrúnmìà can changed one character from bad to good.

(e) One's destiny may be change to worse by the machinations of the 'enikeji' one's heavenly replica from good to bad (146-147).

It is obvious from Ọbasás poetry that he does not get involved in the argument of whether a destiny can change or not. However, in his presentation of ethical issues, one can deduce that he also is of the opinion that one's unpleasant character can bring misfortune unto one, and even one's children. A father that is virtuous automatically extends the benefits of "good life" his children, while a father that embraces wickedness will also bring evil upon his children.

The poet also projected hospitality, kindness, respect for elders, truthfulness, patience, and hard work in his poems. Equally, he condemns vices like lying, adultery, pride, laziness, covetousness, theft, envy, thuggery, and disobedience. It could be averred that one of the things central to Ọbasá's poetry is the moral values as well as their relation to the existent of society. For instance, in the poem titled "Oore", humans are encouraged to do good, because failure to be good will have negative effect on the members of their families. 
In "Òtítọ", the poet also admonishes people to be truthful. The negative impact of getting oneself involved in some vices, like pride and overdoing things is seen in "Alásejù", where he discusses the power tussle between the British government and the Germans during the second World War.

One thing that is glaring is that many of the moral values raised in Obasá's poem fall within the ambit of Yoruba philosophy of ìwà omọlúàbí. In one of his poems, using external coloration from Ifa literary corpus, he extols ìwà rere (good character) above other things:

\section{Excerpt XI}

İwà rere lẹsọ́ ènia

A-bá- mu-rágbá- tagbá

İwà, ìwà là ń wá, ìwà...

Omọ to dára tí kò níwà

Omo-láńgidi ni!

Bobinrin dára bí Egbárá

Bí kò níwà

Omọ lángidi ni!

B'ọkùnrin sunwọn, sunwọn

Bí eja inú omi

Bí kò níwà rere

Omo lángidi ni!

B’enia jọba, bí kò níwà

Omọ lángidi ni! (Ọbasá 1934: 12).

Good character is human's beauty

It is good character we are looking for

A beautiful child without character

Is good for nothing

A lady as beautiful as a beautiful rat

Without characteer

Is good for nothing

A man may be very handsome

Like a fish in the river

If he is without good character

He is good for nothing

If a man is crowned as an Oba

And is without good character

He is good for nothing! 
We can argue from the above excerpt that Obasá recommends the exhibition of good character to every member of society. Children and adults, males and females, as well as rulers and the ruled. In essence, in discussing the issue of Yoruba philosophy about character, the various components of the society are addressed in his poem. Obasá believes in the fact that the true existence of each individual in the society could be found when people relate in moral uprightness with one another. In essence, he is an advocate of everybody having a sense of community in all that is done. If people have a communal sense they will walk in truth, kindness, and hospitality.

Above all, Obasa is also an advocate of the African family. The communal philosophy of what Mbiti (1969) refers to as "I am because we are and since we are therefore I am" (108) drive the ethical issues in his poems. Therefore, in many of his poems, Obasa contends that human does not suffer the outcome of his/her attitude and character alone. Obasa's philosophical position is in tandem with Sartre's (1975) view:

Thus the man who becomes aware of himself through the cogito also perceives others, and he perceives them as a condition of his own existence. He realizes that he cannot be anything unless others recognize it as such. In order to get any truth about myself, I must have contact with another person. The other is indispensable to my own existence, as well as to my knowledge about myself (37-38).

The above position can be vividly seen in Ọbasá view in "Àwọn Ejò", where he encourages working in unity:

Excerpt XII

İbẹrù kò jẹ

Ká tejò mọlẹ

Bí e ti ń rejò tín sá

Bẹl Ejò ń sá pamọ!

Ojú tó bá rọ

Un na ni rore i sọ!

Șe nj Ejò níyà

Ơkan ni ni, e páá

Òun ni yí, e paá

Tani ha jẹ dúró?

Báwọn Sèbé tèle wọn

Káwon Òjòlá má wọ bọ lẹ́hin

Tani ha jẹ dúró? (Ọbasá 1945: 31). 
Fear prevents people from

Trampling on snakes

As the man that spots snakes

Is fearful

So, the snake also is hiding

It is a soft face

That breeds pimples!

The snake suffers because it moves alone

Here is a snake, let's kill it

Here is another one, let's kill it

Who can dare to confront snakes in their multitudes?

Many snakes, with cape-cobra (spit-snake) coming in front

And python-constrictor coming behind,

Who can wait to confront?

The moral lesson in the above excerpt is unity in diversity. Instead of being individualistic, the communal philosophy of the Yoruba should be the watchword. This will have good implications for the growth of Nigeria as a whole and it will promote sustainable development.

Through the use of satire and humor, Obasa' also addresses the philosophy of harmonious living. For instance, Obasá is not a Muslim but he uses his poem to teach religious tolerance, in "Onímọ̀le":

Excerpts XIII

Bísímilái, Lau! Lau!

Lo difá fún Mọle

Abẹwè rẹgèjẹ!

T'ó faiyé gbogbo se fe je

Bìsi ki i là lásán!

Ộré Onímọle l'èmi. (Ọbasá 1934: 9).

Bísímilái, Lau! Lau!

Divine for Muslims

Who uses long garments

Who enjoys every good things

Who just don't pray for fun

Am a friend to Muslims.

Hence, he extols tolerance, and living harmonious life. These are virtues that bring peace and tranquility to society. 


\title{
Didacticism in Obasa's Poems
}

Presentation of didacticism identified in Obasa's poems is in tandem with Bamgbose's (2007) classification on Fagunwa's novels. The five types of didactic presentation are direct, indirect, scenic presentation, reference to folk narratives and humor. It is very difficult to draw a line among these forms of didacticism because there are times when Obasa juxtaposed two or more forms in a poem. However, the form that pervades all the poems in Obasa's poems is indirect didacticism. This is because most of the traditional sayings he assembled are primarily meant for social charter. The sayings are meant to instruct, teach, and moralize. For instance, in the poem "Ahun", a juxtaposed form of didacticism is deployed to teach on the negative side of being stingy. The use of the folktale on Tortoise, the Trickster, is adapted to project a miser and to highlight this basic attribute:

\author{
Excerpt XIV \\ Abahun, Àjàpá \\ Tìrókò, ọo Yánníbo \\ İin ijàpá kì í soso \\ Tani pe e s'Ahun l'óge? \\ Ayán te mi jo \\ Èrà ta mi jọ \\ Atele igi moogun je! \\ Ahun kò pilẹ raṣo ewu \\ À fi bó bá rigbero \\ L'ára aṣo-aláṣọ! (Obasa 1934: 4).
}

Tortoise

The husband of Yannibo

The destiny of tortoise does not decorate

Who asked you to decorate Tortoise?

Cockroach, please gather me together

Ants, please gather me together

Who follows trees to make medicine effective!

Tortoise cares not to buy clothes

Except if it is able to collect

From someone else's clothes.

Using the Tortoise folktales on how the Tortoise depends on others creatures, instead of buying cloth for itself, Obasa projects the miserable and dependent life lived by a miser. This way, Obasa uses stories to deploy 
didacticism. In the same poem, Obasa makes use of indirect didacticism. Indirect didacticism is used when the speaker wants the audience to personally draw meaning from a story or a saying. The indirect and scenic presentation of didacticism unfolds in the poem as the author uses symbolism to depict the end result of being stingy and miserly:

\section{Excerpt XV}

Má ba mi lo sọ mi

Ipárá je e tán nínú okè

Ma bá mi jẹ su mi

Iṣu gbebè o rà si

Ma bá mi jẹkọ mi

Ekọ di bibu sínú ile!

Ma ba mi jeere mi

Eree di jiju sinu ile!

Ma ba mi Kope mi

Eyin dirà sòrun opè

Iyán ahun ni idewu

Obẹ ahun ni i hohi (Ọbasá 1934: 5).

Do not wear my cloth.

The cloth in the sack was eventually eaten by termite

Do not eat my yam

The yam eventually got spoilt in the heap

Do not eat my pap-ball

The pap-ball eventually got spoit

Do not eat my bean

The bean eventually lost its value

Do not harvest my plam kernel bunch.

The palm kernel bunch got spoilt

It is the pounded yam of a miser that also gets spoilt

The soup of a miser grows mold.

In Obasa's attempt to achieve the peak of the didacticism in the poem, he uses a combination of scenic presentation and direct comment to warn the miserly people:

\section{Excerpt XVI}

Ajá-nlapa nitori oo là,

O ko jẹn ka nú?

Ní gbogbo ara gbe bi awo? 
Owó ahun Esu nii ba, a na an

A beeri lójú ọwọ!

À ni k>Ahun o tètè

Fepo okòwó jàgà

O lon ko le

Fepo okòwó jàgá

Epo àrùn pọ ni ton

Ahun fepo arun jàgà

Àgà wú mọ níkùn kalè

O dise epo mimu!

Inu Ahun wu rabata

O ran Yannibo lepo

Așehinwa asẹinbọ

Kinu ahun to role

Epo donigbiwo!

Njẹ tete fepo okòwó jàga (Ọbasá 1934: 5).

Ajanlapa! Because you are poor!

You refuse to feed well?

Imagine your body as dry as hide

It is Eșù that spends the miser's money

Someone with a soiled hand

The tortoise was instructed to sacrifice palm oil

The sacrificing palm oil was too much for his ailment

Since he refused to sacrifice palm oil

His stomach protruded

Then force to lick palm oil

When tortoise had protruding stomach

He sent Yannibo for some palm oil

Eventually before Tortoise regained his good health

Palm oil had cost more

One had better listen to instruction on time.

In the above excerpt, attitude of adoring money and saving money to the detriment of one's health is seen in "Ahun". The scenic presentation of the attitude of a miser, is topped with the direct moralization that a stitch in time saves nine, and that procrastination is the thief of time.

Also, in another poem, "Ọ̀ kànjúà-Olè", Ọbasá adopts a combination of scenic presentation, direct moralization, and indirect didacticism to moralize against theft and coveteousness. In this poem, he starts with scenic presentation; follows it with direct comment, and ends it with indirect moralization: 
Excerpt XVII

Okànjúà t'on tolo

Ogbọogba ni nwọn iṣe!

Okanjuwa bokele,

Oju rẹ la mi!

Ma je su ma jeru

Nibi ayo lo mo

Kòtó, kòtó, ohun t'ole

A fẹru patie ni i to wọn (Ọbasá 1934: 11).

Covetous and stealing

Are equivalent

The covetous one bites a big morsel

That makes his eyes draw tears

Feeding on both small and big pieces of yam

Ends up filling one's stomach

The insatiable one

Ends up not contented

Until he is thoroughly flogged.

He follows the submission on the act of coveteousness and theft with a direct comment on the outcome such an act may have on the children of those involved in such vices:

Excerpt XVIII

Òní sònpọnná ni o pa á

Olá, 'Ṣàngó ni ó pa á'

Òtúnla "Oya ni ó pa á"

Ėpè kò jọmọ olè ó dàgbà (Ọbasá 1934: 11).

Today, may Sanponna kill him

Tomorrow, may Sango kill him

The day after, may Oya kill him

Curses as above make the children of thief die prematurely.

The metaphysical belief in Sonponna, Sango, and Oya among the Yorùbá is also reflected in the above excerpt. These deities are believed to detest stealing. Once they are used to curse a thief the repercussion, it is believed, will be on the thief's children. Hence, the direct didactic import of this excerpt is 
that a thief should desist from stealing in order not to impaired the destiny of his or her children.

Similarly, in the same poem, Obasá deploys indirect didacticism to warn wives that support their husbands to get involved in stealing:

\title{
Excerpt XIX
}

Eẹmejì láya ole isun mú sí

Ijọ tọwo ọko ba de

Asẹda ẹran àjeyi!

T'on t'ata iganran

Ni imú wọn sun mú sí

Ijọ tọwọ ba tọkọ

Orí awe di gbii!

Nidi-ogun l’Ọa ọba. (Ọbasá 1934: 11).

The wife of thief raises her nostrils twice

The day the husband brings home loot

She prepares meat in excess with no pepper

Which makes her raise her nostrils

The day the husband is caught

And beheaded as a sacrifice to Ogun.

The aftermath of stealing in the above is the inferred moralization used to warn on the evil of stealing.

Finally, through the use of satire, Obasá directly moralizes. For instance, in the poem "Ilú Sojá", using the rhythm of drum, he composes a satrical poem to condemn wasteful spending:

\author{
Excerpt XX \\ O tori obinrin búsẹkún \\ Búsẹkún, Busẹkún \\ Ó torí obinrin búsẹkún \\ Omo obinrin ni ó \\ Sá máa yan nisó \\ Se bi ọùnrin \\ Bó bá jáfara \\ Owo otá yo te o \\ O jẹbà, ó jẹ raisi \\ O tún jiyán, ó jàmàlà \\ Ó jẹ dodo, ó jẹà \\ Onijẹkújẹ nì wo
}


Bo bá ńṣe bẹẹ je

O ko lè ni sòkòtò. (Ọbasá 1934: 14).

He wept because of a woman

Weeping! Weeping!!

He wept because of a woman

You were born of a woman

Continue marching on

Act like a man

If you are careless

You will be caught by your enemy

You ate èbà and rice

You ate pounded yam and àmàlà

You ate fried plantain you ate groundnut

You are just eating, anyhow

If you continue eating in this manner

You will not have clothes

If you continue eating in this manner

You will not have any trouser.

The moral import is in the last four lines. It can be deduced in these four lines that if someone indulges in living a riotious life, such a person will end in penury. Also, in "İrẹjẹe" or "Ògbufọ Kewu İbàdàn”, Ọbasá deploys humor to condemn wickedness and to advance the importance of tolerance:

Excerpt XXI

'A-la-mu, tara-kefa

Fa-a-la rà buka"

O ni:

Olọ́run yío mu'ka șùgbọ́n

"Alefi, Ba sin, Lamu

Nugunda, Mimu, Ra, Ja

O ní:

Eni tá bá jùlọ làá irẹjẹ

Mo jù o lọ, mo rẹ o je

O ní:

"Lakum dinni kun

Wali a dinni” (Obasá 1945: 34).

'A-la-mu, tara-kefa

Fa-a-la rà buka" 
Which means:

God will apprehend the wicked but

"Alefi, Ba, Sin, Lamu

Nugunda, Mimu, Ra, Ja

Which means:

One cheats on anybody junior to him//her

I cheat you because I am your senior

"Lakun dinni kun,

Wali a dinni

Meaning - practice your religion

While I should be allowed to practice mine.

The first two lines of the above excerpt is an introductory Arabic verse in the Quran that usually precedes prayer and call to Allah (God), but the poet changes its meaning to condemn the vice of wickedness. This teaches that the Supreme Being will deal with the wicked, hence, people should stop wickedness. He goes further to humorously pronounce some Arabic letters and change the meanings to project the evil of cheating an elderly person. In short, Ọbasá, through his poems, advances the ideology of ìwà ọmọúàbí that gives prominence to respect for elders. He preaches religious tolerance in the last part of the satirical projection of the act of some imaginary deceptive interpreters.

\section{Conclusion}

This essay has examined how Obasa has successfully deployed his poetic creation to expound the Yoruba philosophy. The paper stressed that some of the philosophical tenets embedded in Obasá's poetry are for didactic import. All the five forms of didacticism are deployed by Obasa to strengthen philosophical ideas of his poems. The philosophical tenets, apart from instructing, teaching, and moralizing are also for creating a social order. Some tenets of philosophy, like metaphysics, ethics and epistemology, are reflected in Obasá's poetry. This essay affirmed that there is a close link between poets and philosophers. The ethical issues identified in the poems are for the promotion of authentic existence, a form of existentialism that is based on putting the society before an individual. Therefore, the paper advocates that the sustainable development desired by the Nigerian society would be a reality if the Yoruba philosophy embedded and moralized in Obasa's poems are taught and imbibed by all. 


\section{Work Cited}

Abimbọlá, Wande. Ifá: An Exposition of Ifá Literary Corpus. Ibadan: Ibadan Oxford University Press Nigeria, 1976.

Adejumo, Arinpe. "Africa and the Challenges of Good Governance and Development: A Cultural-Literary Perspective." Paper Presented at the Faculty of Arts Third Biennial International Conference, University of Ibadan, 14-18 March, 2017.

Adeleke, Duro. "Communication in the Yoruba Court: Reflections from Yoruba Video Films." Revista do Centro de Estudos Africanes. 27.28. (2007): 115-133.

Akinyemi, Akintunde. "Adenrele Adeetimikan Obasá (1927-1945): Àkéwì Aláròjinlẹ." Unpublised M.A. Thesis, University of Ife, Nigeria, 1987. “Ākóónú Ewì Àpilệkọ Ọbasá." In Sola Adebajo (ed.).

Semina Ni Iranti J.S.A. Odujinrin. 100 - 122. Ago Iwoye: Ogun State University, 1991.

. “D.A. Obasá (1879-1945): A Yoruba Poet, Culture

Activist and Local Intellectual in Colonial Nigeria." Africa. 87.1, (2017): $1-15$.

Babalola. A and A. Gerard. (1971) "A Brief Survey of Creative Writing in Yoruba." Black Africa 2. (1971): 113- 125.

Bamgbose, Ayo. The Novels of D.O. Fagunwa- A Commentary. Ibadan: Nelson Publishers Limited, 2007.

Bamikole, Lawrence. "The Ethics of Work in Sholla-Allyson Obanuji's Máròsẹ» Yoruba: Journal of Yoruba Studies Association of Nigeria. 8.4, (2017): 38-71.

Idowu, Bolaji. African Traditional Religion: A Definition. London. S.C.M. Press, 1974. . Olódùmarè: God in Yorùbá Belief. London: Longman, 1962.

Makinde, M.A. "Immorality of the Soul and the Yoruba Theory of Seven Heavens." Journal of Culture and Ideas. 1.1, (1983): 31-59.

Mbiti, J.S. African Religion and Philosophy. London: Heinemann Educational Books Ltd, 1969.

Barricelli Jeane-Pierre and Gilbaldi Joseph (eds.). Interrelation of Literature. New York: The Mordern Language Association of America, 1982.

Obasa, D.A. Iwe Kiini ti Awon Akewi (Yoruba Philosophy). Ibadan: Ilare Press 1927.

1934. . Iwe Keji ti Awon Akewi (Yoruba Philosophy). Ibadan: Ilare Press

Obasa, D.A. Iwe Keta ti Awon Akewi (Yoruba Philosophy). Ibadan: Ilare Press 1945. 
Oguejiofor, J.O. Philosopy and the African Predicament. Ibadan. Hope Publications, 2004.

Ogunsina, Bisi. The Development of Yorùbá Novel. Ilorin: Gospel Faith Publisher, 1991.

Olatunji, O.O. Adebayo Faleti: A Study of His Poem (1945-1964). Ibadan: Heinemann Educational Books, 1982.

Olabimtan, Afolabi. "A Critical Survey of Yoruba Written Poetry, 1848-1948." Unpublished Ph.D. Thesis, University of Lagos, Nigeria, 1974.

. "Language and Style in Obasa's Poetry." In Wande Abimbola (ed.) Yoruba Oral Tradition 1031-1069, Ife: African Languages, Series No 1, 1975.

. "Isẹ́ Akéwì Nínú Ètò àtì Ẹ̀tọ İlú" Olátúnjí O (ed.) Yorùbá: A Language in Transition. 59-100. Ibadan, J.F. Odunjọ Memorial Lecture Series. 1988. 59-100.

Oladipo, O. "Knowledge and the African Renaisance." In L.O. Bankole (ed.) Essays in Comparative Philosophy. 65-77. Ilorin: Majab Publishers. 2002.

Olajide, Wale. "Orí as Deity among the Yorùbá: Some Philosophical and Linguistic Clarifications." Yoruba: Journal of Yorùbá Studies Association of Nigeria. 7.1, (2012): 135- 154.

Oyeshile. O.A. "Beyond Religious and Ethnic Identities: The Imperative of Sense of Community in Citizenship." In F. Adesanoye (Ed.), Religion, Ethnicity and Citizenship. 29-87. Ibadan: An Occasional Publication of Nigerian Academy of Letters. No 15. 2017.

Oyewale. A.S. "A Comparative Examination of Philosophical Themes in the Poetic Works of Olatunbosun Oladapo and Ifayemi Eleibuibon." Unpublished Ph.D Thesis, University of Ibadan, 2014. 